\title{
Newly identified genes linked to endometrial receptiveness: lessons from IVF
}

\begin{abstract}
"Successful implantation depends on synchronization between the developmental stages of the embryo itself and the complex series of molecular and cellular events induced in the endometrium by paracrine and autocrine regulators during the implantation window."
\end{abstract}

A total of 30 years after the first in vitro fertilization (IVF) birth in the world, pregnancy and birth rates following IVF attempts remain low. Indeed, two out of three IVF cycles fail to result in pregnancy, and more than 9 out of 10 transferred embryos fail to implant [1]. Although the selection of high-quality embryos and endometrial status assessment have seen important technological progress, implantation rates are still low after controlled ovarian hyperstimulation (COS) for IVF [2]. Implantation failure is thought to result from impairment of embryo development and/or from abnormal uterine receptivity. The endometrium is receptive to blastocyst implantation during a spatially and temporally restricted window, 'the implantation window' [3]. In humans, this period begins 6-10 days after the lutenizing hormone (LH) surge and lasts approximately $48 \mathrm{~h}[4,5]$.

\section{"Although the selection of high-quality embryos and endometrial status assessment have seen important technological progress, \\ implantation rates are still low after \\ controlled ovarian hyperstimulation for in vitro fertilization"}

\section{Human endometrial receptivity during natural cycles}

Successful implantation depends on synchronization between the developmental stages of the embryo itself and the complex series of molecular and cellular events induced in the endometrium by paracrine and autocrine regulators during the implantation window. This explains that there are many molecular marker candidates to determine the 'ideal' endometrium receptive period [6-10]. Several parameters have been suggested for assessing endometrial receptivity, including endometrial thickness (a classical criterion), endometrial morphology aspect and endometrial and subendometrial blood flow using ultrasonography and Doppler (Figure 1), noninvasive methods to evaluate uterine receptivity $[6,7,9,11]$. However, such indirect explorations result in controversy, and their positive predictive value is limited [12-14]. Emerging technology in the assessment of the gametes, competent embryos and endometrial receptivity, the omics allow the identification of biomarkers or to determine the molecular signature of endometrial cells specific to endometrial receptivity. More recently, transcriptomic approaches have been used to identify biomarkers of the human implantation window. Using microarray technology in human biopsy samples, several authors have observed modifications in gene expression profiles associated with the transition of the human endometrium from a prereceptive ( $\mathrm{LH}+2 / 4$ days) to a receptive (LH + 7/9 days) state (Table 1) [15-19]. However, among the various regulated genes, only two genes were in common between all these studies: secreted phosphoprotein (SPP) 1, a glycoprotein involved in cellular adhesion and migration during embryo implantation, and IL15, a progesterone-regulated gene involved in stages immediately before, during and after the apposition step and permitting adequate proliferation of the stroma [20,21]. Disparities between these studies [15-19] may be explained by several factors: type of microarray used, data analysis, statistical methodologies, size of patient samples, ages of subjects and sampling time during the cycle. In addition, only two studies compared the early- and mid-secretory phases in the same patient $[16,18]$, which seems a necessary condition to minimize the impact of interpatient variability. Incorporating these conditions and using a large series of patients (in

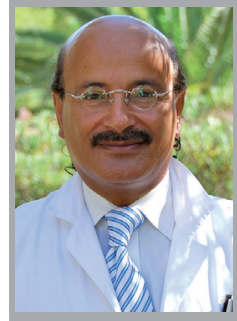

Samir Hamamah

Author for correspondence:

ART/PGD Division, Arnaud

de Villeneuve hospital,

34295-Montpellier, France

Tel.: + 33467336404

Fax: +33467336290 ;

E-mail:s-hamamah@

chu-montpellier.fr

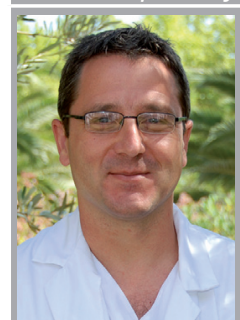

Hervé Dechaud

ART/PGD Division, Arnaud

de Villeneuve hospital,

34295-Montpellier, France

Tel.: + 33467336404 ;

Fax: +33467336290 ;

E-mail:h-dechaud@

chu-montpellier.fr 

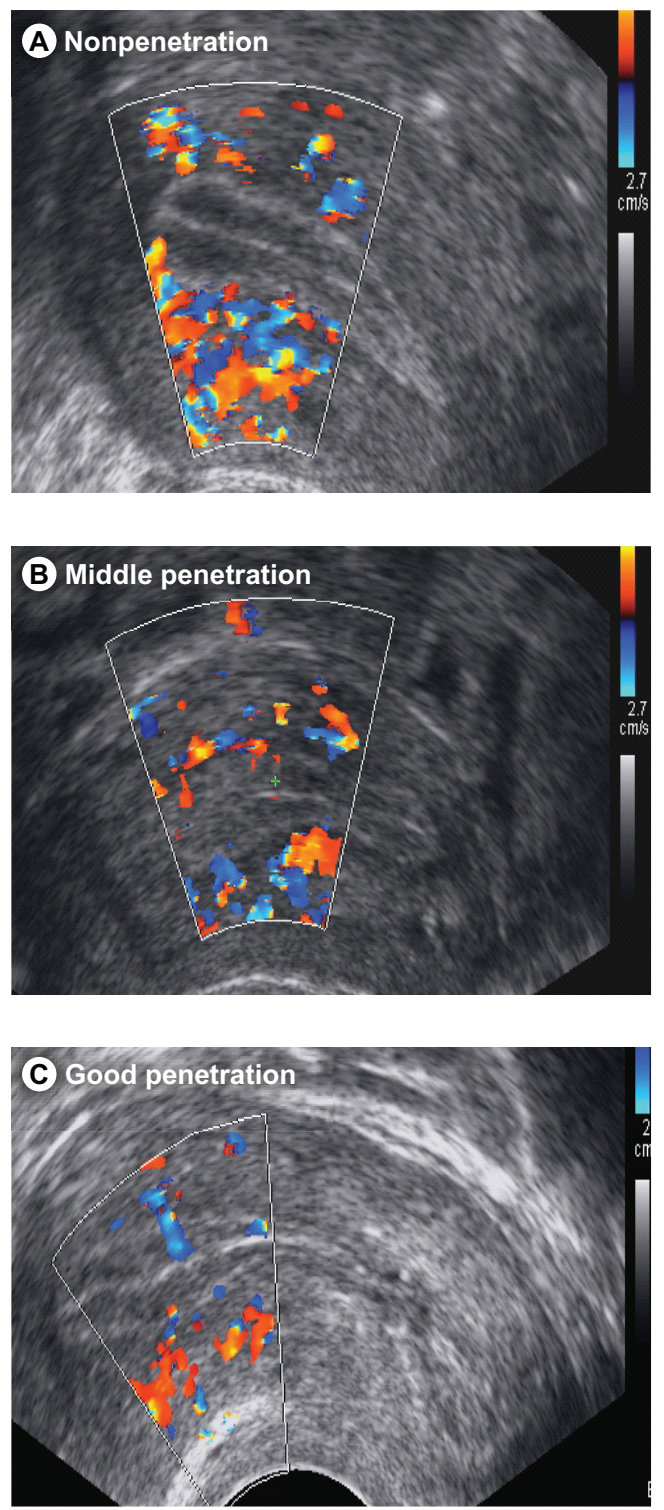

Figure 1. Ultrasonography is useful for evaluating endometrial receptivity.

contradiction to Riesewijk's study), we identified four new biomarkers of endometrial receptivity that were upregulated in the $\mathrm{LH}+7$ days samples compared with the $\mathrm{LH}+2$ days samples. These biomarkers are MFAP5, ANGPTL1, EG-VEGF and NLF2, and play a role in the extracellular matrix remodeling of the endothelial cell microenvironment, angiogenesis and the formation of the endothelial fenestration. This group of genes shows potential to be useful prognostic markers of endometrium receptivity (Figure 2).

\section{Human endometrial receptivity during COS cycles}

COS is a key factor in the success of IVFembryo transfer (ET). Studies comparing $\mathrm{GnRH}$ agonist long protocols with GnRH

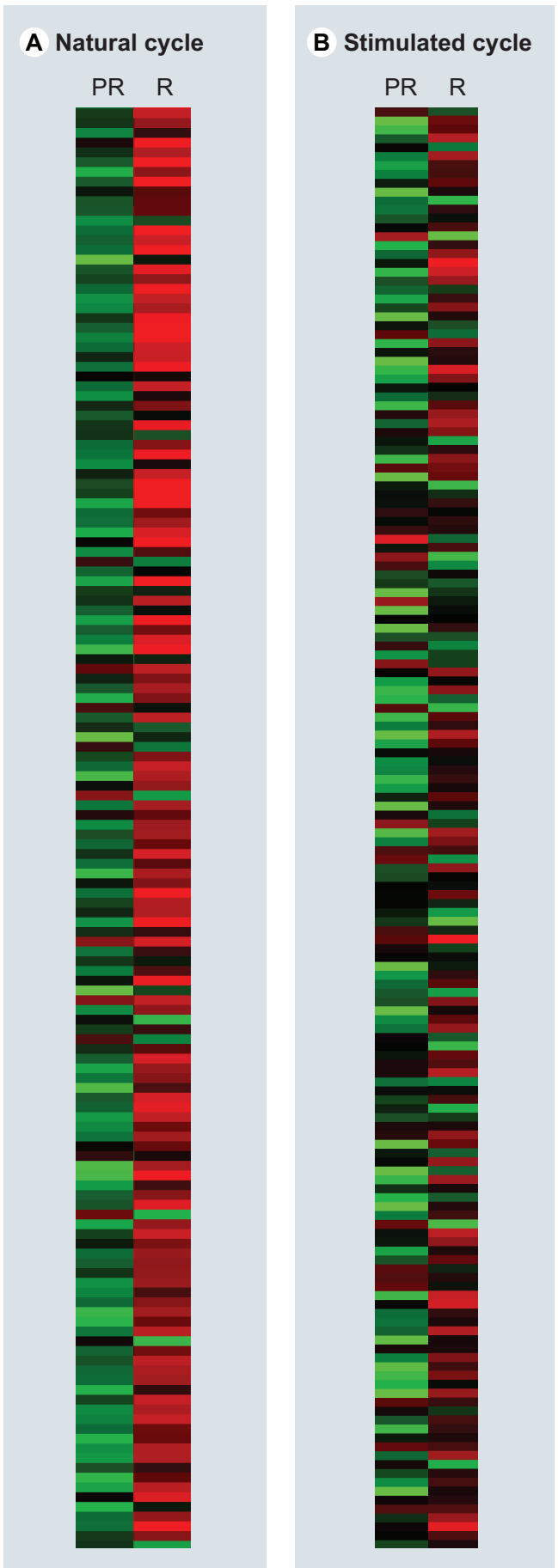

Figure 2. Endometrial profiles during the prereceptive and the receptive stages in natural and stimulated cycles. Hierarchical clustering between $\mathrm{LH}+2$ days and $\mathrm{LH}+$

7 days samples, and between hCG +2 days and hCG +5 days samples. Red: upregulated genes; Green: downregulated genes.

hCG: human chorionic gonadotropin; PR: Prereceptive; R: Receptive.

antagonist protocols remain controversial, and the impact of these protocols on endometrial receptivity has yielded conflicting results (TaBLe 1) [22-26]. Several studies have shown that gene 
Table 1. Number of genes significantly modulated in microarray comparison analyses between the early- and mid-secretory stages of the natural and stimulated endometrium cycle.

\begin{tabular}{|c|c|c|c|c|c|c|}
\hline \multirow[t]{2}{*}{ Study } & \multirow[t]{2}{*}{$\begin{array}{l}\text { First sample: (number } \\
\text { of samples) }\end{array}$} & \multirow[t]{2}{*}{$\begin{array}{l}\text { Second sample: (number } \\
\text { of samples) }\end{array}$} & \multirow[t]{2}{*}{$\begin{array}{l}\text { Fold } \\
\text { change }\end{array}$} & \multicolumn{2}{|c|}{$\begin{array}{l}\text { Number of } \\
\text { genes }\end{array}$} & \multirow[t]{2}{*}{ Ref. } \\
\hline & & & & Up & Down & \\
\hline Mirkin et al. (2005) & $\mathrm{LH}+3(3)$ & $\mathrm{LH}+8(5)$ & $\geq 2$ & 49 & 58 & {$[17]$} \\
\hline Riesewijk et al. (2003) & $\mathrm{LH}+2(5)$ & $\mathrm{LH}+7(5)$ & $\geq 3$ & 153 & 58 & {$[18]$} \\
\hline Talbi et al. (2006) & $\operatorname{ESP}(3)$ & MSP (8) & $\geq 1.5$ & 1415 & 1463 & {$[19]$} \\
\hline \multirow[t]{2}{*}{ Mirkin et al. (2004) } & $\mathrm{LH}+8(5)$ & hCG + 9 Atg (5) & $\geq 1.19$ & 6 & 6 & {$[25]$} \\
\hline & $\mathrm{LH}+8(5)$ & $h C G+9 \mathrm{Ag}(3)$ & $\geq 1.2$ & 5 & 5 & \\
\hline Horcajadas et al. (2005) & $\mathrm{LH}+7(14)$ & $\mathrm{hCG}+7(5)$ & $\geq 3$ & 281 & 277 & [24] \\
\hline Simon et al. (2005) & $\mathrm{LH}+7(14)$ & hCG + 7 Atg standard dose (4) & $\geq 2$ & 22 & 69 & [26] \\
\hline \multirow[t]{2}{*}{ Liu et al. (2008) } & $\mathrm{LH}+7(5)$ & hCG + 7 high serum E2 levels (4) & $\geq 2$ & 244 & 159 & {$[23]$} \\
\hline & $\mathrm{LH}+7(5)$ & hCG + 7 low serum E2 levels (4) & & 5 & 2 & \\
\hline
\end{tabular}

expression profiles associated with endometrial receptivity during COS (human chorionic gonadotropin $[\mathrm{hCG}]+7 / 9)$ were closer to those in natural cycles $(\mathrm{LH}+7 / 8)$, either under $\mathrm{GnRH}$ antagonist or agonist treatments $[25,26]$. However, the number of genes significantly modulated under COS in comparison with natural cycles was very different between these two studies (112 genes under GnRH antagonist treatment in Simon's study vs 12 genes in Mirkin's study; 122 genes under GnRH agonist treatment in the Simon's study vs six genes in Mirkin's study). Finally, Simon's study concluded that endometrial development during cycles using GnRH antagonists was found to be histologically more similar to those from natural cycles than endometrium exposed to GnRH agonists [26]. Horcajadas's study revealed that endometrial development was hampered during COS cycles, as judged by the number of genes significantly modulated under COS cycles in comparison with natural cycles (558 genes), showing gene expression levels more similar to those in a nonreceptive endometrium [24]. More precisely, they have demonstrated the existence of a 2-day delay in the activation/repression of two clusters composed of 218 and 133 genes, respectively, on day hCG +7 versus $\mathrm{LH}+7$, affecting the endometrial receptivity process [22]. More recently, it has been reported that impairment of endometrial receptivity was due to a high concentration of steroids resulting from COS $[23,27]$.

\section{"...it has been reported that impairment of endometrial receptivity was due to a high concentration of steroids resulting from controlled ovarian hyperstimulation..."}

Therefore, the real challenge is to perform COS treatment modifications to achieve a receptive endometrium that morphologically and functionally resembles the natural receptive endometrium, which will subsequently lead to improved success rates in IVF.

\section{Financial \& competing interests disclosure}

The authors have no relevant affliations or financial involvement with any organization or entity with a financial interest in or financial conflict with the subject matter or materials discussed in the manuscript. This includes employment, consultancies, honoraria, stock ownership or options, expert testimony, grants or patents received or pending, or royalties.

No writing assistance was utilized in the production of this manuscript. 


\section{Bibliography}

1 Kovalevsky G, Patrizio P: High rates of embryo wastage with use of assisted reproductive technology: a look at the trends between 1995 and 2001 in the United States. Fertil. Steril. 84(2), 325-330 (2005).

2 Donaghay M, Lessey BA: Uterine receptivity: alterations associated with benign gynecological disease. Semin. Reprod. Med. 25(6), 461-475 (2007).

3 Paria BC, Lim H, Das SK, Reese J, Dey SK: Molecular signaling in uterine receptivity for implantation. Semin. Cell Dev. Biol. 11, 67-76 (2000).

4 Martin J, Dominguez F, Avila S et al.: Human endometrial receptivity: gene regulation. J. Reprod. Immunol. 55, 131-139 (2002).

5 Wilcox AJ, Baird DD, Weinberg CR: Time of implantation of the conceptus and loss of pregnancy. N. Engl. J. Med. 340, 1796-1799 (1999).

6 Abate V, De Corato R, Cali A, Stinchi A: Endometrial biopsy at the time of embryo transfer: correlation of histological diagnosis with therapy and pregnancy rate. $J$. In vitro Fert. Embryo Transf. 4, 173-176 (1987).

7 Aghajanova L, Hamilton AE, Giudice LC: Uterine receptivity to human embryonic implantation: histology, biomarkers and transcriptomics. Semin. Cell. Dev. Biol. 19(2), 204-211 (2008).

8 Horcajadas JA, Riesewijk A, Dominguez F, Cervero A, Pellicer A, Simon C: Determinants of endometrial receptivity. Ann. NY Acad. Sci. 1034, 166-175 (2004).

9 van der Gaast MH, Beier-Hellwig K, Fauser BC, Beier HM, Macklon NS: Endometrial secretion aspiration prior to embryo transfer does not reduce implantation rates. Reprod. Biomed. Online 7, 105-109 (2003).

10 Edwards RG: Human implantation: the last barrier in assisted reproduction technologies? Reprod. Biomed. Online 13, 887-904 (2006).
11 Dechaud H, Bessueille E, Bousquet PJ, Reyftmann L, Hamamah S, Hedon B: Optimal timing of ultrasonographic and Doppler evaluation of uterine receptivity to implantation. Reprod. Biomed. 16(3), 368-375 (2008).

12 Alcázar JL: Three-dimensional ultrasound assessment of endometrial receptivity: a review. Reprod. Biol. Endocrinol. 9(4), 56 (2006).

13 Friedler S, Schenker JG, Herman A, Lewin A: The role of ultrasonography in the evaluation of endometrial receptivity following assisted reproductive treatments: a critical review. Hum. Reprod. Update 2, 323-335 (1996).

14 Pierson RA: Imaging the endometrium: are there predictors of uterine receptivity? J. Obstet. Gynaecol. Can. 5, 360-368 (2003).

15 Carson DD, Lagow E, Thathiah A et al.: Changes in gene expression during the early to mid-luteal (receptive phase) transition in human endometrium detected by highdensity microarray screening. Mol. Hum. Reprod. 8(9), 871-879 (2002).

16 Haouzi D, Mahmoud K, Fourar M et al.: Identification of new biomarkers of human endometrial receptivity in the natural cycle. Hum. Reprod. 24, 198-205 (2009).

17 Mirkin S, Arslan M, Churikov D et al.: In search of candidate genes critically expressed in the human endometrium during the window of implantation. Hum. Reprod. 20(8) 2104-2117 (2005).

18 Riesewijk A, Martín J, van Os R et al.: Gene expression profiling of human endometrial receptivity on days $\mathrm{LH}+2$ versus $\mathrm{LH}+7$ by microarray technology. Mol. Hum. Reprod. 9(5), 253-264 (2003).

19 Talbi S, Hamilton AE, Vo KC et al.: Molecular phenotyping of human endometrium distinguishes menstrual cycle phases and underlying biological processes in normo-ovulatory women. Endocrinology 147(3), 1097-1121 (2006).
20 Lédée N, Dubanchet S, Oger P et al.: Uterine receptivity and cytokines: new concepts and new applications. Gynecol. Obstet. Invest. 64(3), 138-143 (2007).

21 von Wolff M, Strowitzki T, Becker V, Zepf C, Tabibzadeh S, Thaler CJ: Endometrial osteopontin, a ligand of $\beta 3$-integrin, is maximally expressed around the time of the 'implantation window'. Fertil. Steril. 76(4), 775-781 (2001).

22 Horcajadas JA, Mínguez P, Dopazo J et al: Controlled ovarian stimulation induces a functional genomic delay of the endometrium with potential clinical implications. J. Clin. Endocrinol. Metab. 93(11), 4500-4510 (2008).

23 Liu Y, Lee KF, Ng EH, Yeung WS, Ho PC: Gene expression profiling of human peri-implantation endometria between natural and stimulated cycles. Fertil. Steril. 90 (6), 2152-2164 (2008).

24 Horcajadas JA, Riesewijk A, Polman J et al:: Effect of controlled ovarian hyperstimulation in IVF on endometrial gene expression profiles. Mol. Hum. Reprod. 11(3), 195-205 (2005).

25 Mirkin S, Nikas G, Hsiu JG, Díaz J, Oehninger S: Gene expression profiles and structural/functional features of the peri-implantation endometrium in natural and gonadotropin-stimulated cycles. J. Clin. Endocrinol. Metab. 89(11), 5742-5752 (2004).

26 Simon C, Oberyé J, Bellver J et al: : Similar endometrial development in oocyte donors treated with either high- or standarddose $\mathrm{GnRH}$ antagonist compared with treatment with a GnRH agonist or in natural cycles. Hum. Reprod. 20(12), 3318-3327 (2005).

27 Krikun G, Schatz F, Taylor R et al.: Endometrial endothelial cell steroid receptor expression and steroid effects on gene expression. J. Clin. Endocrinol. Metab. 90(3) 1812-1818 (2005). 